\title{
Lightweight sintered aggregate as construction material in concrete structures
}

\author{
Robert Grygo ${ }^{1, *}$, and Victor Pranevich ${ }^{2}$ \\ ${ }^{1}$ Department of Building Structures and Architecture, Bialystok University of Technology, Bialystok, \\ Poland \\ ${ }^{2}$ Department od Building Structures and Architecture, Bialystok University of Technology, Bialystok, \\ Poland
}

\begin{abstract}
The paper presents the result of testing a new patented lightweight aggregates. The only solid material used to manufactured these aggregate is fly ash. Lightweight sintered aggregate is durable, lightweight and high-strength material. It is environmentally friendly material. It has chance to by future material in concrete use. The laboratory test shown that the concrete made from the this special lightweight sintered aggregate possesses low porosity, high strength and high durability potential. The bulk density, depending on the product fraction, oscillates between 550 $830 \mathrm{~kg} / \mathrm{m}^{3}$. This special lightweight sintered aggregate has also high resistance to crushing, when we compare to another lightweight aggregate.
\end{abstract}

\section{Introduction}

Increasing consumption of aggregates, especially in countries with dynamically developing economy and environmental protection, cause that in many developed countries produces aggregates of alternative raw materials against to mineral resources. Therefore it is important to find an alternative. Artificial aggregates are produced from various types of waste materials, produced mainly in the steel industry, energy and mining. Type of raw material has a big influence on the strength parameters obtained aggregates. Recycled aggregates are producing in the construction works, such as demolition and reconstruction of building, roads, etc. Besides the above, on the market increasingly is noted group of aggregates produced from waste minerals released by the underground mining of coal and ore. From the reasons stated above, it is proposed to introduce a new distribution of aggregates [1], other than natural, as shown in Fig.1. Another problem is the availability and ease to exploitation of building aggregates. As for the fine aggregate, sand distribution is generally uniform and easy to explore. By contrast, mining of natural coarse aggregates, are distributed unevenly are distributed unevenly and often in Europe expensive in maintenance cost. On the basis of results of our own experimental studies on model beams [2], [3], it was confirmed some significant differences in the behavior of flexural structural elements made of recycled aggregate concrete (RAC), compared to members made of concrete with natural aggregate.

\footnotetext{
* corresponding author: r.grygo@pb.edu.pl
} 
The beams made of RAC cracked earlier and showed greater deflections at comparable loads. The concrete strains in the most stressed compressive zone of such beams were higher by about $45 \%$ of the strains in the reference beams made of natural aggregate, whereas the mean values of strains in the tension zone were comparable. RC beams made of RAC showed lower flexural capacity of 5 to $7 \%$, compared to reference beams, made of natural aggregate concrete with similar class of compressive strength. There were no differences observed in the mechanism of destruction, all the beams were destroyed as expected, by the yielding of the reinforcement in the tension zone. The subject of the use of recycled aggregates and aggregates alternative is carried out also by other researchers [4], $[5]$.

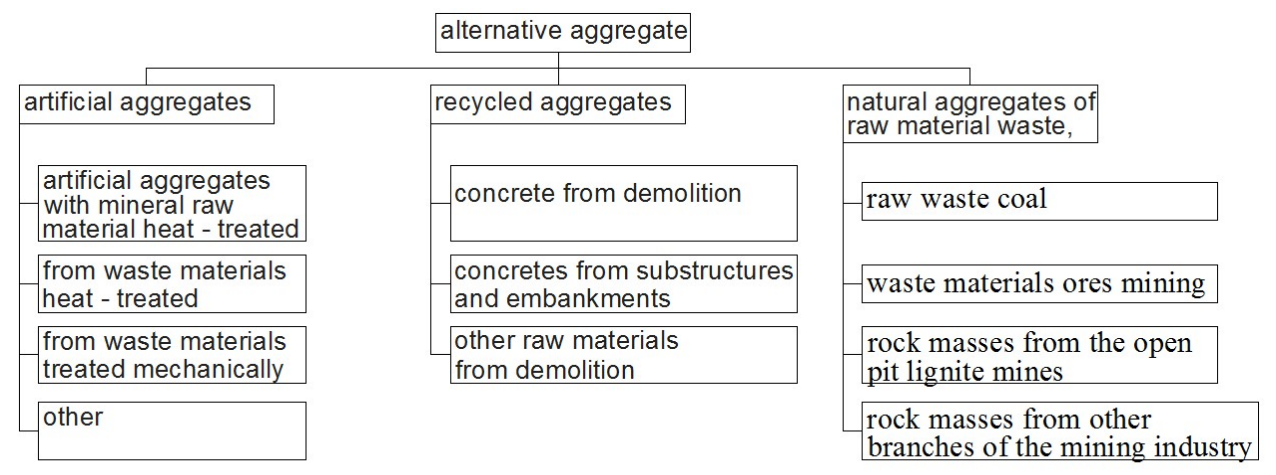

Fig. 1. Distribution of alternative aggregates [1]

An interesting alternative may be the use of lightweight aggregates. An interesting alternative may be the use of lightweight aggregates, especially those aggregates which have excellent properties. One possibility is Certyd aggregate [6]. The only solid material used to manufactured these aggregate is fly ash. This special lightweight sintered aggregate is durable, lightweight and high-strength material.

The use of lightweight aggregate in concrete has many advantages:

- reduction in the sizes of construction elements like columns, slabs and beams,

- $\quad$ lighter and smaller precast elements needing smaller and less expensive transporting

equipment,

- enhanced fir resistance,

- high thermal insulation,

- reduction of reinforcement;

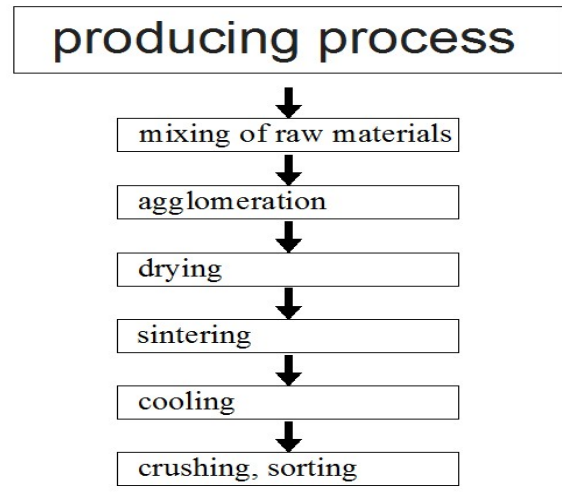

Fig. 2. The process of production of lightweight sintered aggregate 
One of the most imported thing is also thermal properties. Walls and floors made of lightweight sintered aggregate concrete have a high thermos-insulating performance, and perfectly protect against high and low temperature. The process of producing of lightweight sintered aggregate aggregates shown on fig. 2 .

The lightweight sintered aggregate characteristics and properties comply with lightweight aggregate standards (e.g. PN-EN 13055-1 Lightweight aggregates for concrete, mortar and grout, PN-EN 13055-2 Lightweight aggregates for bituminous mixtures and surface treatments and for unbound and bound applications). The tested lightweight sintered aggregate is an ideal alternative for agloporite aggregate, granulated slag or pumice-stone slag, as one of the main components of lightweight structural and pervious concretes. With the bulk density of $550-830 \mathrm{~kg} / \mathrm{m} 3$ it can be easily used for making lightweight concretes with the weight starting at $1400 \mathrm{~kg} / \mathrm{m} 3$ (where the concrete weight made of natural aggregate is usually placed between $2400-2800 \mathrm{~kg} / \mathrm{m} 3$ ). It is the only aggregate on the market which can be used to make lightweight concrete with high durability. It is also possible to make high strength concretes HSC (over $60 \mathrm{MPa}$ ). The view of aggregates shown in fig 3 . The basic aggregates properties are presented in the table 1 .

Table 1. The basic properties of tested lightweight sintered aggregate

\begin{tabular}{|l|c|c|c|}
\hline \multirow{2}{*}{} & \multicolumn{3}{|c|}{ Fractions } \\
\cline { 2 - 4 } & $1-4$ & $4-8$ & $8-16$ \\
\hline Bulk density [kg/m $\left.{ }^{3}\right]$ & $620 \pm 10 \%$ & $700 \pm 10 \%$ & $725 \pm 10 \%$ \\
\hline $\begin{array}{l}\text { Resistance to crushing } \\
{\left[\mathrm{N} / \mathrm{mm}^{2}\right]}\end{array}$ & - & $>6,0$ & $>5,0$ \\
\hline $\begin{array}{l}\text { thermal conductivity } \\
\text { coefficient [W/m-k] }\end{array}$ & 0,16 & 0,14 & 0,16 \\
\hline $\begin{array}{l}\text { Absorbability after 24 hours } \\
{[\%]}\end{array}$ & - & 20 & $17-19$ \\
\hline Frost resistance [\%] & - & 1,00 & 1,00 \\
\hline
\end{tabular}

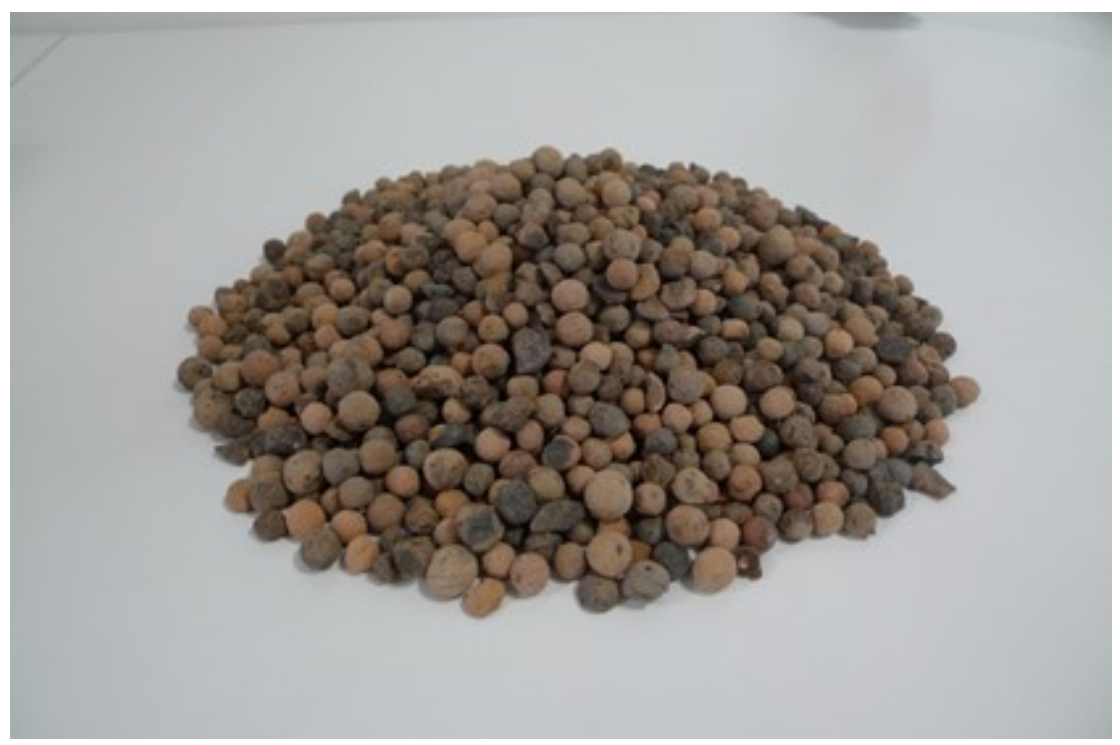

Fig. 3. Uncompressed state of tested aggregates 


\section{Own research of lightweight sintered aggregate}

In own studies, was performed recipes of lightweight aggregate concrete. One of the key issues was to make prescriptions with regard to the economic characteristics. A common concept used to indicate the maximum compressive and splitting tensile strengths of concretes using lightweight aggregate is a "strength ceiling." A mixture reaches its strength ceiling when, using the same aggregate, it possesses only slightly higher strength with higher cement content. This property is predominantly influenced by the coarse aggregate fraction of the mixture. The strength ceiling can be increased by reducing the maximum size of the coarse aggregate. As with normal weight concrete, water reducing and mineral admixtures can be used with lightweight concrete to improve the workability, placing, and finishing. Freezing and thawing resistance and permeability are important factors in the durability of concrete. For freezing and thawing resistance, properly proportioned and placed lightweight concrete has been found to perform as well or better than normal weight concrete. The permeability of lightweight concrete has been found to be equal to or less than that of normal weight concrete. This is attributed to the elastic compatibility of the constituents and the enhanced bond between the coarse aggregate and the cement paste. Reduced permeability and increased resistance to the effects of freezing and thawing lead to a more durable concrete that is better able to resist corrosion of steel in concrete. The recipe is shown in Table 2.

Table 2. The basic properties of tested aggregates

\begin{tabular}{|l|l|c|}
\hline \multicolumn{1}{|c|}{ Materials } & \multicolumn{1}{c|}{ Source } & $\mathrm{kg} / \mathrm{m} 3$ \\
\hline CEM I 42,5R & Warta & $\mathbf{4 3 0}$ \\
\hline Water & city water & $\mathbf{1 8 6}$ \\
\hline Sand & Suwalki & $\mathbf{6 8 0}$ \\
\hline tested agg. 2/4 & LSA & $\mathbf{3 3 6}$ \\
\hline tested agg. 4/8 & LSA & $\mathbf{1 6 8}$ \\
\hline Chryso Spolos TB & Chryso & $\mathbf{3 , 1 6}$ \\
\hline Chryso Air A10 & Chryso & $\mathbf{0 , 5 4}$ \\
\hline
\end{tabular}

It was extremely important also to determine the correctness of the destruction of concrete samples in testing machine. The destruction of the lightweight concrete samples looks different than aggregate natural concrete. Such destruction is done by cutting the aggregate. The effect of destruction is shown in Figure 4 


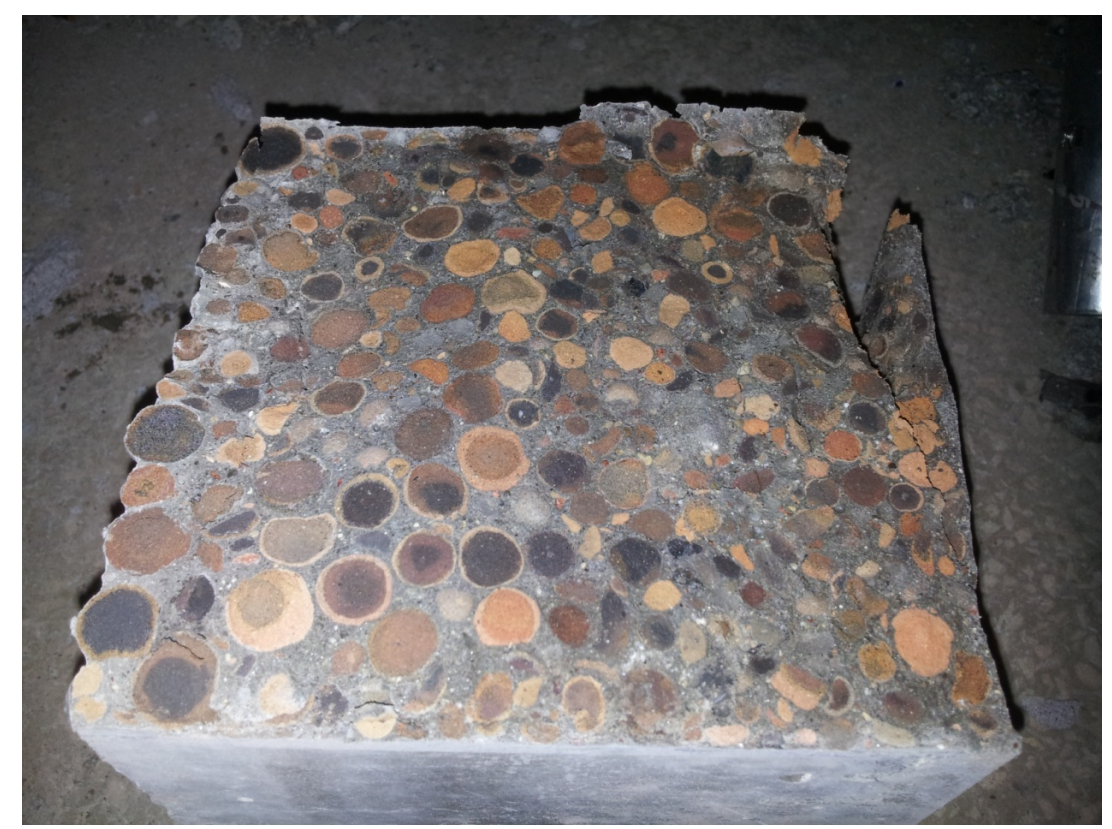

Fig. 3. Tested Concrete sample after the destruction

Concrete compressive strength after 7 and 28 days are shown in Tables 3 and 4 . The results of compressive strength after 150 cycles of freezing are shown in Table 5. The results given in Tables 3 and 4 show that concrete made tested lightweight aggregate can achieve high compressive strengths.

Table 3. Concrete compressive strength after 7 days

\begin{tabular}{|c|c|}
\hline Samples, weight & Strength \\
\hline $15^{\times} 15^{\times} 15,6544 \mathrm{~g}$ & $53,44 \mathrm{MPa}$ \\
\hline $15^{\times} 15^{\times} 15,6458 \mathrm{~g}$ & $56,71 \mathrm{MPa}$ \\
\hline $15^{\times} 15^{\times} 15,6932 \mathrm{~g}$ & $51,13 \mathrm{MPa}$ \\
\hline
\end{tabular}

Table 4. Concrete compressive strength after 28 days

\begin{tabular}{|c|c|}
\hline Samples, weight & Strength \\
\hline $10^{\times} 10^{\times} 10,1907 \mathrm{~g}$ & $73,35 \mathrm{MPa}$ \\
\hline $10^{\times} 10^{\times} 10,1894 \mathrm{~g}$ & $74,58 \mathrm{MPa}$ \\
\hline $10^{\times} 10^{\times} 10,1877 \mathrm{~g}$ & $69,56 \mathrm{MPa}$ \\
\hline $10^{\times} 10^{\times} 10,1905 \mathrm{~g}$ & $73,12 \mathrm{MPa}$ \\
\hline $10^{\times} 10^{\times} 10,1944 \mathrm{~g}$ & $64,64 \mathrm{MPa}$ \\
\hline $10^{\times} 10^{\times} 10,1914 \mathrm{~g}$ & $69,18 \mathrm{MPa}$ \\
\hline
\end{tabular}


Table 5. Test after 150 cycles of freezing and thawing

\begin{tabular}{|c|c|c|}
\hline $\begin{array}{c}\text { Sample, original } \\
\text { weight }\end{array}$ & $\begin{array}{c}\text { Weight after } 150 \\
\text { cycles }\end{array}$ & Strength \\
\hline $10^{\times} 10^{\times} 10,1925 \mathrm{~g}$ & $1923 \mathrm{~g}$ & $67,69 \mathrm{MPa}$ \\
\hline $10^{\times} 10^{\times} 10,1898 \mathrm{~g}$ & $1898 \mathrm{~g}$ & $71,29 \mathrm{MPa}$ \\
\hline $10^{\times} 10^{\times} 10,1918 \mathrm{~g}$ & $1916 \mathrm{~g}$ & $57,05 \mathrm{MPa}$ \\
\hline $10^{\times} 10^{\times} 10,1928 \mathrm{~g}$ & $1919 \mathrm{~g}$ & $67,77 \mathrm{MPa}$ \\
\hline $10^{\times} 10^{\times} 10,1828 \mathrm{~g}$ & $1898 \mathrm{~g}$ & $55,19 \mathrm{MPa}$ \\
\hline $10^{\times} 10^{\times} 10,1921 \mathrm{~g}$ & $1909 \mathrm{~g}$ & $50,55 \mathrm{MPa}$ \\
\hline
\end{tabular}

For the verification of the results statistical analyses were carried out of the uncertainty of the results of strength tests. The standard deviations determined using a development of the $\mathrm{F}(\mathrm{xi})$ function in a Taylor series with correlated xi, xk input sizes using the formula prof. Brunarskiego [6].

The standard deviation was determined using the expansion of the function $F\left(x_{i}\right)$ in a Taylor series with sizes correlated input $\mathrm{x}_{\mathrm{i}}, \mathrm{x}_{\mathrm{k}}$ using the formula (1):

$$
u_{c}(y)=\sqrt{\sum_{i=1}^{N}\left(\frac{\delta y}{\delta x_{i}}\right)} \cdot u^{2}\left(x_{i}\right)+2 \sum_{i=1}^{N-1} \sum_{k=i+1}^{N}\left(\frac{\delta y}{\delta x_{i}}\right)\left(\frac{\delta y}{\delta x_{k}}\right) u\left(x_{i}, x_{k}\right)
$$

where:

$\mathrm{X}_{\mathrm{i}}, \mathrm{X}_{\mathrm{k}}$ - estimates of correlated input quantities $\mathrm{X}$,

$\mathrm{x}\left(\mathrm{x}_{\mathrm{i}}, \mathrm{x}_{\mathrm{k}}\right)=\mathrm{u}\left(\mathrm{x}_{\mathrm{k}}, \mathrm{x}_{\mathrm{i}}\right)$ - covariance estimator related $\mathrm{z} \mathrm{x}_{\mathrm{i}}, \mathrm{x}_{\mathrm{k}}$

Summary of test results:

Coefficient of variation of concrete strength

$$
v_{\text {cube }}=\frac{s_{\text {cube }}}{f_{c, \text { cube }}^{-}}+d f
$$

Expression of the function of the output - average compressive strength $\mathrm{f}_{\mathrm{cm}}$

$$
f_{c m}=\frac{1000 F}{d^{2}}+d f, \mathrm{MPa}
$$

Calculation of component standard uncertainties $u_{i}\left(f_{c m}\right)$ :

a) a first component associated with force measurement $F$ in the testing machine class 1 assumed equal $\delta F= \pm 0,01 \mathrm{~F}$, from here

standard uncertainty of type B with formulas (4)

$$
u\left(x_{i}\right)=\frac{\delta x_{i}}{\sqrt{3}}=0,58 \delta x_{i}
$$

Component of the standard uncertainty associated with the first output quantity $\mathrm{F}$ by the formula (5)

$$
u(y)=\left|\frac{\delta y}{\delta x_{i}}\right| u\left(x_{i}\right)
$$


b) the second component associated with the measurement of the dimensions of the compression surface of the sample $\mathrm{d}$ :

for samples taken in the forms of code can be assumed that the dimensions of the sides of the cube $d=$ const or the error of their measurement $d f=0$, hence the standard uncertainty of type B of formula (6)

$$
u\left(x_{i}\right)=\frac{\delta x_{i}}{\sqrt{3}}=0,58 \delta x_{i}
$$

partial derivative $f_{c m}$ with respect to $\mathrm{d}$

$$
\frac{\delta f_{c m}}{\delta d}=-\frac{2 \times 1000 F}{d^{3}}
$$

component of the standard uncertainty associated with a second output quantity $\mathrm{d}$ from the formula (8)

$$
u_{d}\left(f_{c m}\right)=\left|\frac{\delta f_{c m}}{\delta d}\right| u(d)=0
$$

c) the third component associated with improved df, taking into account the random nature of the concrete strength:

- the standard deviation of the mean compressive strength, determined from examination of a series of samples of size $n=3$, the formula is (9):

$$
s=\frac{R}{\alpha_{n}}, R=y_{n}-y_{1}
$$

where:

- $\quad$ R- gap in a series of size $\mathrm{n}$ ordered ascending test results, it is the difference between the results of research: the highest $y_{n}$ and lowest $y_{l}$

- $\quad \alpha_{n}-$ coefficient depending on the number of results $\mathrm{n}$.

- component of the standard uncertainty of third the size of the input $\mathrm{d} f_{c m}$ from formula (10)

$$
u_{d f}\left(f_{c m}\right)=\left|\frac{\delta f_{c m}}{\delta(d f)}\right| u(d f)
$$

The compressive strength of the concrete $\quad 48,08<\mathrm{f}_{\mathrm{cm}}<64,17$

\section{Conclusions}

The study confirmed the high efficiency of the use of tested lightweight aggregate. It is possible to use in the future, after studys of such aggregates in structures like bridges and tall buildings. It is also important to make a research on structural elements like beams and columns. 


\section{References}

1. Kozioł W., Kawalec P. Kruszywa alternatywne w budownictwie. Nowoczesne Budownictwo Inżynieryjne, 7-8 2008, pp.34-37

2. Grygo, R., Chyży, T., Lapko, A., 2011. Modeling of local strengthening of RC beams made of recycled aggregate concrete using HPC, International Conference on Engineering UBI2011, 28-30 Nov 2011. University of Beira Interior - Covilhã, Portugal.

3. Lapko, A., Grygo, R., 2011. Flexural capacity and deformability of RC beams with the use of recycled aggregate concrete, Sbornik Naučnyh Trudov Instituta Stroitel'stva i Arhitektury MGSU, Moskva 3, pp. 53-57.

4. Domski, J., Katzer, J., 2013. Load - deflection characteristic of Fibre Concrete Based on Waste Ceramic Aggregate. Annual Set The Environment Protection, Vol. 15, pp. 213-230.

5. www.certyd.pl

6. Brunarski L.: Instrukcje, Wytyczne, Poradniki ITB, nr 435/2008: „Wyznaczanie niepewności wyników badań wytrzymałościowych, Poradnik”. ITB, Warszawa 2008 